\title{
9. TEMPERATURES, HEAT FLOW, AND LITHOSPHERIC COOLING AT THE MOUTH OF THE GULF OF CALIFORNIA ${ }^{1}$
}

\author{
B.T.R. Lewis, Department of Oceanography and Geophysics Program, University of Washington, Seattle, Washington
}

\begin{abstract}
Downhole temperatures and sediment thermal conductivities measured on Leg 65 of the Deep Sea Drilling Project were found to agree very closely with conventional seafloor heat flow measurements made at the same sites. This indicates that the seafloor heat flow data are an accurate representation of the heat flowing through the sediments. Three out of four of the heat flow values agree very well with the Parker-Oldenburg cooling model in the age range $0.5 \mathrm{~m} . \mathrm{y}$. to 2.4 m.y., suggesting that at the mouth of the Gulf of California loss of heat due to convection of water is not as important as in other areas. This conclusion is consistent with the geologic structure obtained from drilling - sequences composed predominantly of massive basalts interlayered with sediments-which are likely to be relatively impermeable. However, temperatures inferred at the bottom of the crust, assuming conductive cooling and laboratory measurements of thermal conductivities, lead to predicted seismic velocities substantially lower than those observed. This suggests that although the surface layers may be impermeable, the heat transport at depth may have a convective component, or the effective thermal conductivity at depth may be significantly higher than that of basalt, or a combination of both.
\end{abstract}

\section{INTRODUCTION}

An important aspect of the evolution of the oceanic crust is the role that seawater serves in transporting heat out of the crust during its early history. Critical questions are: How deep does water penetrate? What is the permeability of the crust? What role does water play in crustal metamorphism? There is already a substantial body of data on seabottom heat flow, suggesting that convection of seawater within the crust plays a major role in cooling young, hot crust (e.g., Lister, 1972; Williams et al., 1974; Anderson et al., 1977).

In order to test this, one of the principal objectives of Leg 65 was to drill a deep hole into extremely young $\mathrm{Pa}$ cific crust. Site 482 , located on 0.4 m.y. old crust about $12 \mathrm{~km}$ from the ridge axis, was the prime site for this hole. Unfortunately, shipboard difficulties prevented us from drilling to a depth that would have provided really useful thermal measurements, the deepest hole at this site penetrating only 92 meters of basalt. Nonetheless, this remains the youngest crust drilled to date and during the drilling of this and other sites on Leg 65 , temperature measurements were made downhole.

Although we did not obtain the data needed to address the primary problem, sufficient data were obtained to: (1) Evaluate the accuracy of extrapolating conventional seafloor temperature gradients to depth in the sediments; (2) Provide upper bounds on temperatures within the basalts; and (3) Provide some evidence for active upward transport of heat by water within the crust.

In this chapter, temperature results from Sites 482 , 483 , and 485 will be described and combined with data from Leg 64, Site 474.

\footnotetext{
${ }^{1}$ Lewis, B. T. R., Robinson, P., et al., Init. Repts. DSDP, 65: Washington (U.S. Govt. Printing Office).
}

\section{SITE DESCRIPTION}

The general locations of Sites $482,483,485$, and 474 are shown in Figure 1. Sites 482 and 485 were both east of the rise axis in two adjacent sediment ponds at distances of about 13 and $26 \mathrm{~km}$ from the axis on $0.45 \mathrm{~m} . \mathrm{y}$. and $0.85 \mathrm{~m}$.y. old crust, respectively. Site 483 was about $70-\mathrm{km}$ west of the axis on $2.4 \mathrm{~m}$.y. old crust, and Site 474 was at the foot of the Baja slope on crust which is about $3.5 \mathrm{~m} . \mathrm{y}$. old.

Figure 2 shows the topographical relationship of Sites 482 and 485 to the rise axis, and Figures 3 and 4 show detailed reflection profiles across Sites 482 and 485 . Site 483 was located in an area with very smooth, flat basement close to a seamount. Figures 5 and 6 show the reflection profiles across the site, which indicate the smooth nature of basement and the relationship of the site to the seamount.

All three drill sites intersected 100 or more meters of hemipelagic clays underlain by massive basalt flows which had interlayered sediments and, in the case of 483 , substantial interlayered pillow basalts. Lithologic columns for these sites are shown in Figure 7.

A reflection profile across Site 474 is shown in Figure 8 , indicating the relationship of this hole to the margin and the presence of a thin transparent layer which may be a recent turbidite deposit. Site 474 drilling revealed a pillow basalt basement at 562.5 meters sub-bottom overlain by two dolerite sills between 521 meters and basement (Curray et al., in press).

\section{CONVENTIONAL SEAFLOOR HEAT FLOW MEASUREMENTS}

As part of the University of Washington's site survey of this area prior to drilling, conventional seafloor heat flow measurements were made, using an instrument loaned to us by C. Lister and described by Lister (1970). This instrument measures the thermal gradient in the 


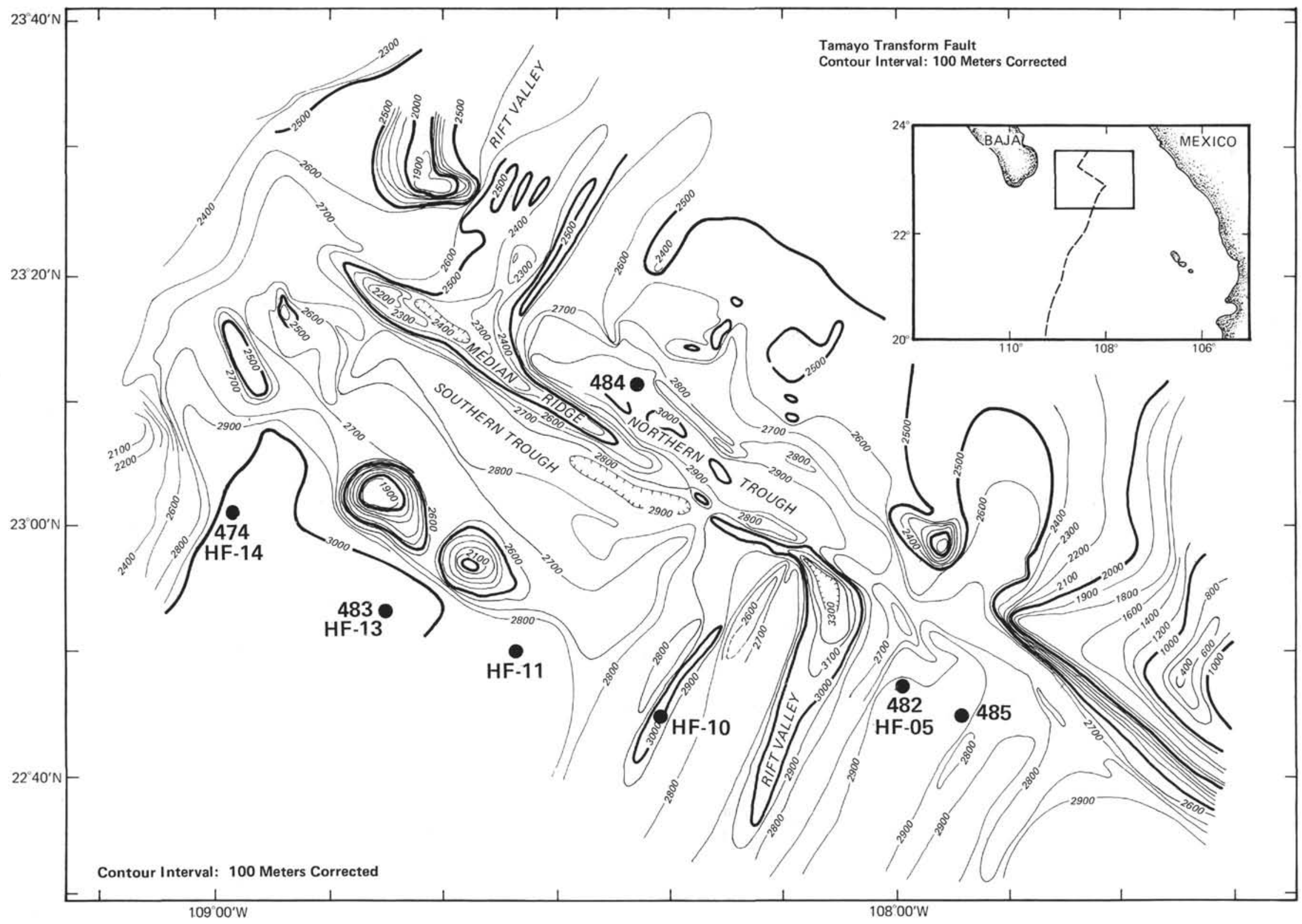

Figure 1. Locations of drill sites and heat flow stations used in this study. 
Figure 2. Locations of Heat Flow Stations HF-05 and HF-10 and DSDP Sites 482 and 485 with respect to the East Pacific Rise. (Seismic reflection profile TT-099, line 8 from site survey chapter, this volume.)

NW

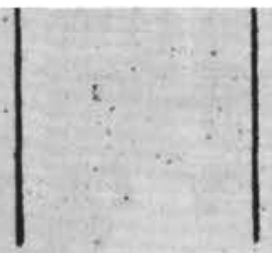

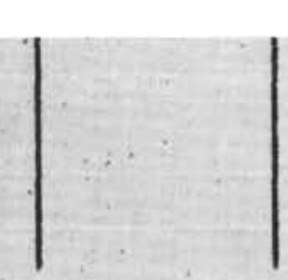
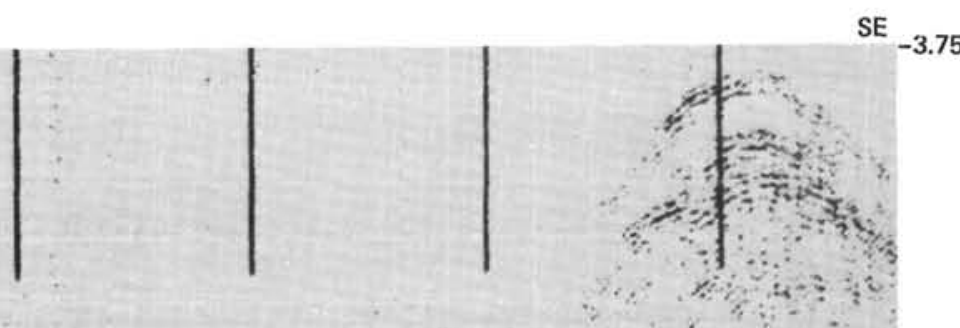

\section{$1 \times$}

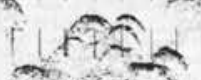

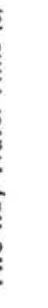




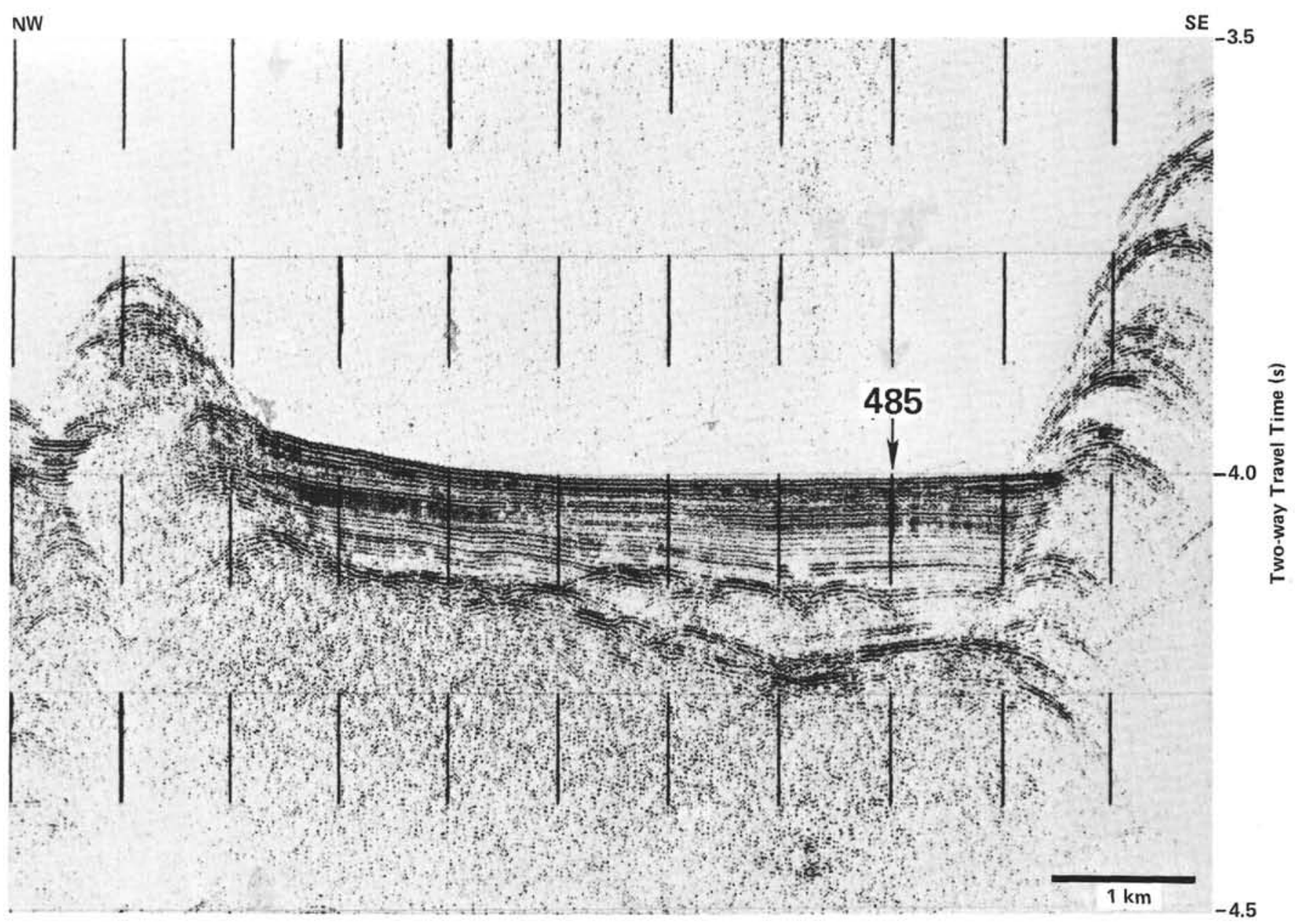

Figure 4. Expanded view of reflection profile shown in Figure 2 across Site 485.

upper 2 meters of sediment and the in situ thermal conductivity by observing the time decay of a heating pulse.

Five successful heat flow measurements were made over oceanic crust ranging in age from $0.5 \mathrm{~m}$.y. to 3.5 m.y. The data for these stations are summarized in Table 1. Three of these heat flow sites were later drilled during Legs 64 and 65 . On Leg 64, Site 474 was drilled close to Station HF-14, which is on the oldest oceanic crust adjacent to Baja California. On Leg 65, Sites 482 and 483 were drilled close to Stations HF-05 and HF-13, respectively. This allowed a comparison to be made between downhole temperatures and extrapolated seafloor temperature gradients.

\section{DOWNHOLE TEMPERATURE MEASUREMENTS}

Two methods were available on the Glomar Challenger to measure downhole temperatures; one employed the Tokyo T-Probe, the other employed a standard logging tool.

The Tokyo T-Probe is mounted in a core barrel and is lowered or can free fall to the bottom of the drill string where the temperature probe protrudes beyond the bit by about 1 meter. Once the probe is in place the drill string is lowered so that the probe is pushed into the sediments at the bottom of the hole. This method, of course, requires that the sediments are soft enough for this to occur without bending the probe. Temperature data are taken once every minute and stored in a digital memory for later readout in the shipboard laboratory. Since with this method the temperature is measured ahead of the drill hole, equilibration is rapid and corrections for drilling disturbance are small (Hyndman et al., 1976) compared to measurements of the temperature of the water in the hole. During our use of the instrument, temperatures were encountered that were higher than the calibration curves supplied. Calibration was achieved to about $75^{\circ} \mathrm{C}$ by immersing the probe in a bucket of hot water and comparing the readout to standard thermometers.

The logging method uses temperature measurements of the water in the hole to infer surrounding formation temperatures. During a temperature logging run, the probe is run down the drill string and out of the end of the pipe into the open hole. While the probe is being lowered, seawater is pumped down the drill string in order to maintain tension on the logging cable. Normally the probe is held at the bottom of the hole for several minutes before the logging run uphole is begun. This method provides a minimum estimate of the temperature since the hole is usually far from thermal equi- 


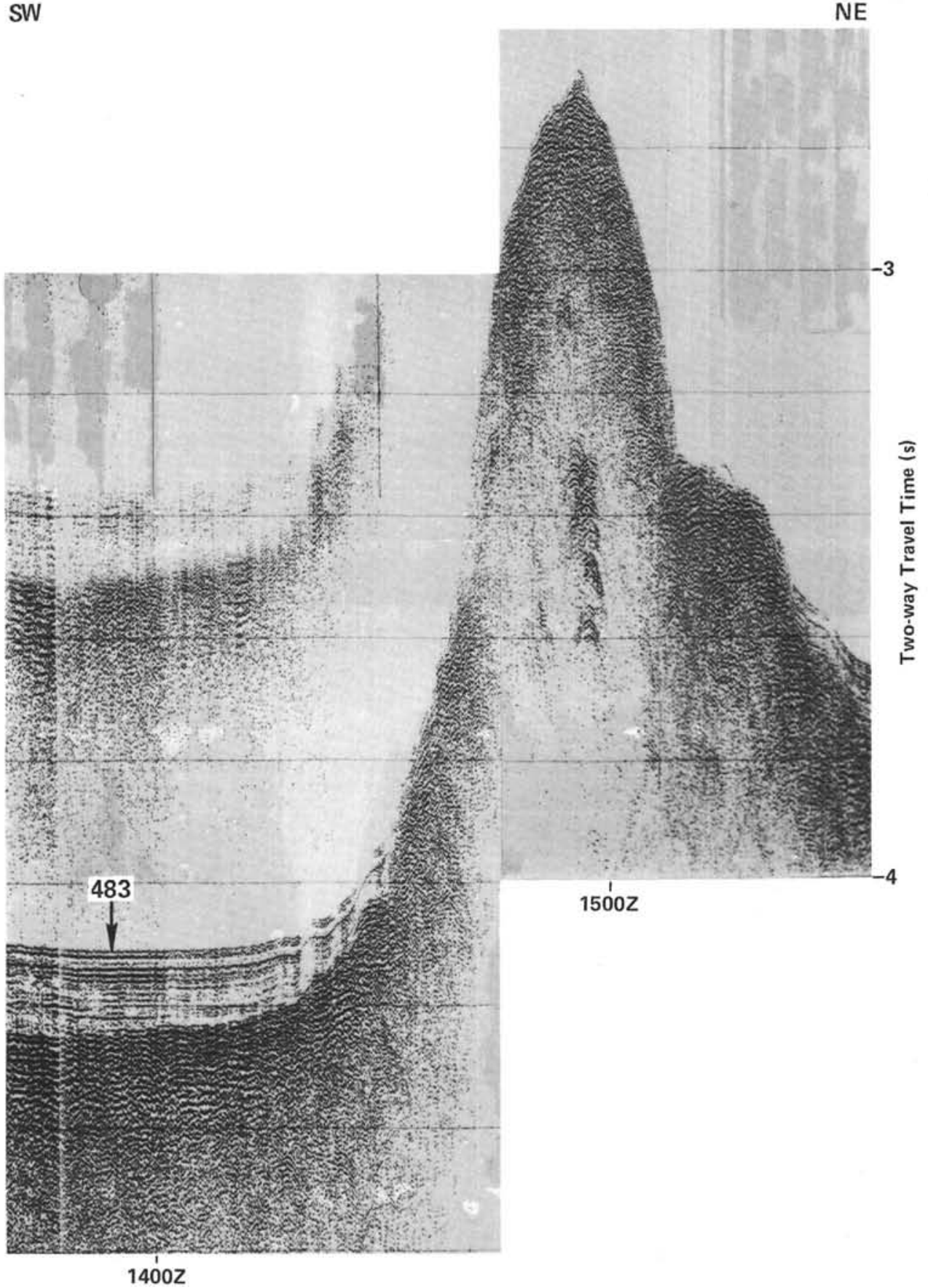

Figure 5. Expanded view of Glomar Challenger reflection profile across Site 483, showing the relationship of the site to the seamount to the northeast. (Horizontal scale given in time along ship's track. One hr. represents about $10 \mathrm{~km}$.)

librium and the effect of pumping water down the hole during drilling and logging is to depress the temperature by a large but unknown amount.

Wherever possible we used the Tokyo T-Probe to measure downhole temperatures. Results will be presented on a site-by-site basis in the order that these were drilled, except for Site 474, which was drilled on Leg 64.

\section{Site 482, 0.4 m.y.}

At Site 482, three successful measurements were made with the Tokyo T-Probe in Hole 482C. Plots of observed temperature vs. time from the time the instrument was inserted into the sediments to the time it was withdrawn are shown in Figure 9. Inferred equilibrium temperatures were obtained by visually extrapolating the curves to large values of time. This technique is justified here because the formation temperatures were considerably higher than heating effects caused by insertion of the tool into the sediments (see Hyndman et al., 1976).

The temperature inferred for the bottom of the sediments at Site 482 from these measurements was 85 to 


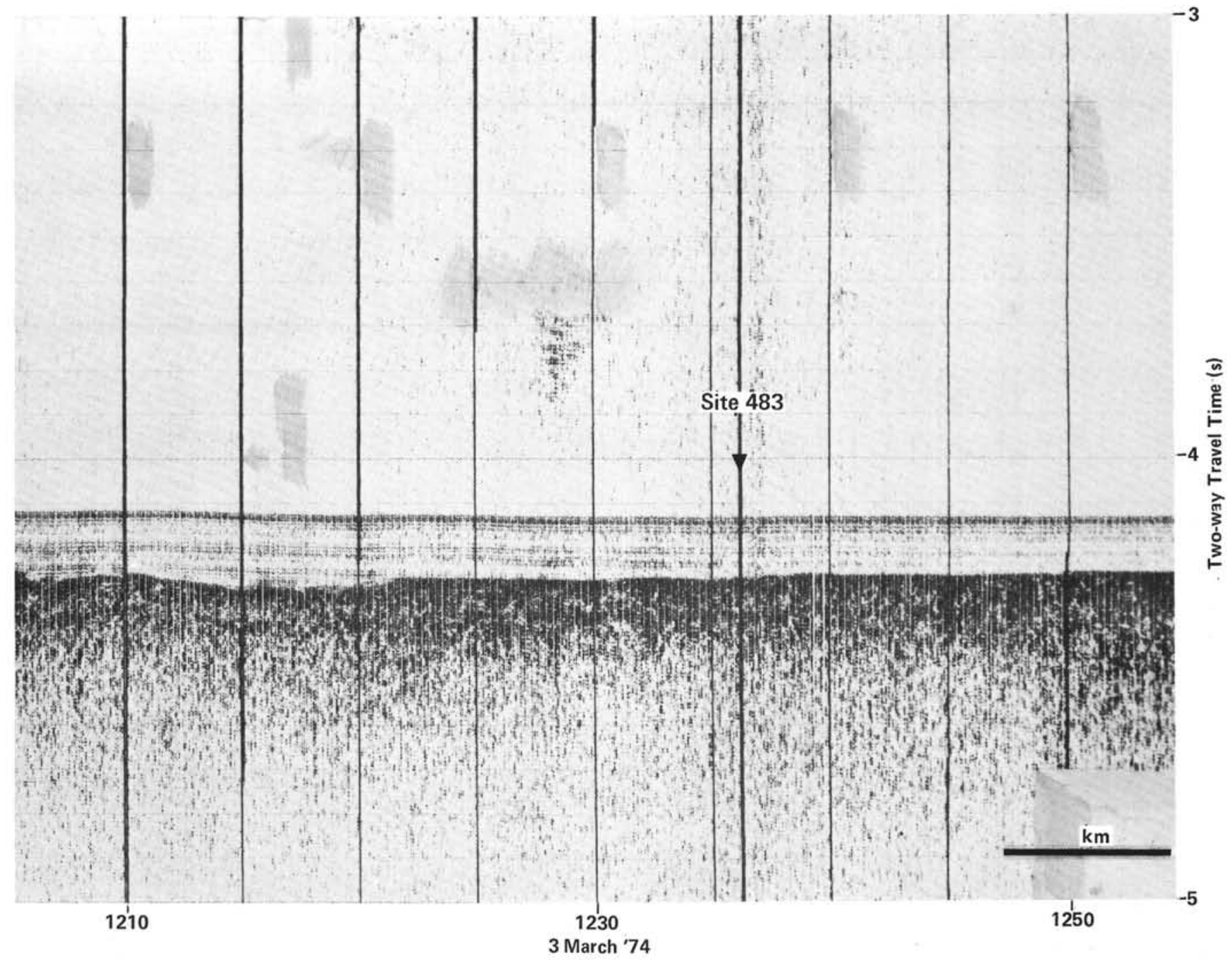

Figure 6. Expanded view of Glomar Challenger reflection profile across Site 483, showing the flat-lying massive basalt basement. Reflectors within basement may result from interlayered sediment. (Horizontal scale given in time along ship's track. One hr. represents about $10 \mathrm{~km}$.)

$90^{\circ} \mathrm{C}$. Hole $482 \mathrm{~B}$ was finally drilled to 92 meters below the sediments (or $240 \mathrm{~m}$ sub-bottom), and to obtain an estimate of the temperature in the basalts at the bottom of the hole the logging tool was used. The highest temperature obtained by the $\log$ was $40^{\circ} \mathrm{C}$ at 9 meters from the bottom of the hole. This is clearly well below the probable temperature.

The Hawaii Institute of Geophysics downhole seismometer was placed in Hole $482 \mathrm{C}$, and this device recorded temperature. The highest temperature obtained before the recording package was lowered to the seafloor was $60^{\circ} \mathrm{C}$. This instrument was later recovered, and it was found that the electronic components and a level bubble had been damaged by high temperatures. Duennebier et al. (1980) estimate from the nature of the damage that the temperature could ultimately have been as high as $150^{\circ} \mathrm{C}$. This is considerably higher than the $100^{\circ} \mathrm{C}$ value that was estimated from projecting the sediment temperatures into the basalt using measured thermal conductivities. If the $150^{\circ} \mathrm{C}$ estimate is correct, it could imply that hot water was entering the hole from below.
Site 483, 2.4 m.y.

Two successful temperature measurements were made in Hole $483 \mathrm{C}$ using the Tokyo T-Probe. The temperature-time histories of these measurements are shown in Figure 10. The measurement at 86 meters depth appears to be degraded by the fact that the tool was withdrawn and reinserted into the sediments during the run. The inferred basement temperature in this hole is about $28^{\circ} \mathrm{C}$.

\section{Site 485, 0.85 m.y.}

No successful temperature measurements using the Tokyo T-Probe were made at Site 485. Two temperature logging runs were made two days apart before and after deployment of the Stevens downhole seismometer for the oblique seismic experiment. The maximum temperature recorded at the bottom of the hole $(300 \mathrm{~m}$ below the seafloor) during the first run was $28.5^{\circ} \mathrm{C}$ and the maximum two days later was $36^{\circ} \mathrm{C}$. Because these measurements were made in the water in the hole and the tool was pumped down, these must be lowest estimates of the formation temperature. The experience at Site 482 


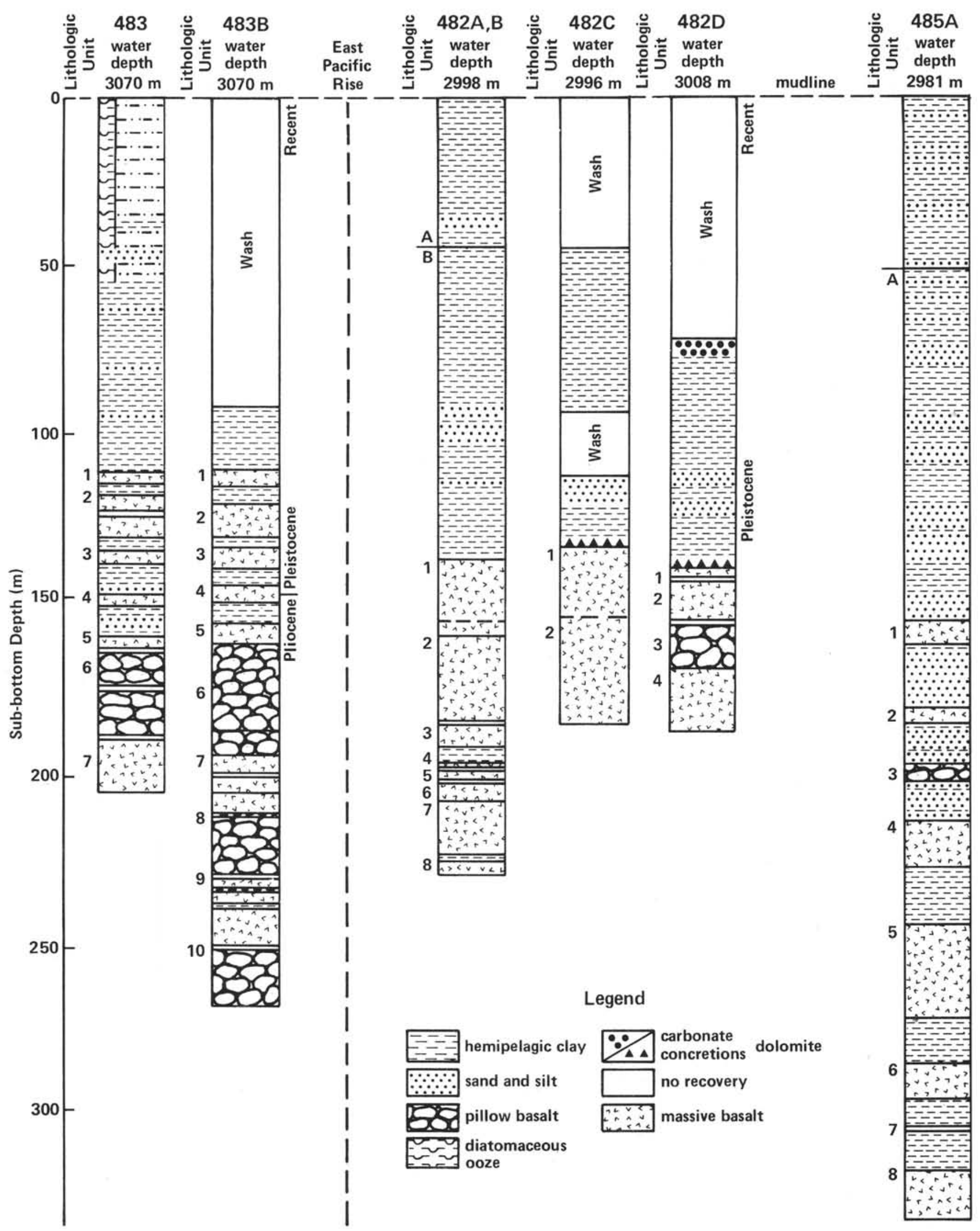

Figure 7. Lithologic columns for Leg 65 sites. 


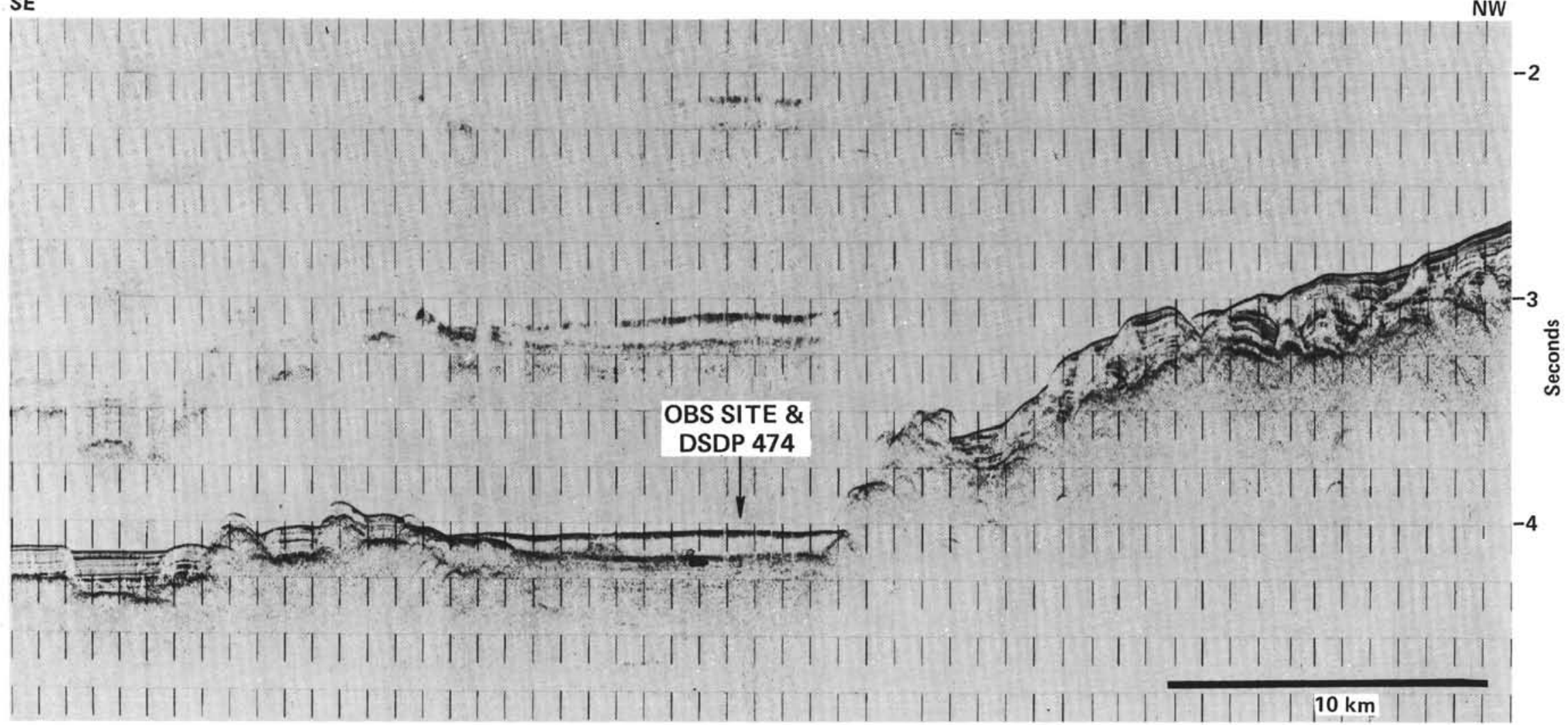

Figure 8. Reflection profile across Site 474, which is located close to the point marked OBS site. (Profile represents segment of reflection profile TT-099, line 6 from site survey chapter, this volume.) 
Table 1. Heat flow from Thomas G. Thompson, Cruise TT-099.

\begin{tabular}{|c|c|c|c|c|c|c|c|c|c|c|}
\hline Site & $\begin{array}{l}\text { U.W. } \\
\text { Station } \\
\text { No. }\end{array}$ & Latitude & Longitude & $\begin{array}{l}\text { Gradient } \\
\left({ }^{\circ} \mathrm{C} / \mathrm{m}\right)\end{array}$ & $\begin{array}{l}\text { Conductivity } \\
\left(\mathrm{cal} / \mathrm{cm} \mathrm{s}^{\circ} \mathrm{C} \text { ) }\right.\end{array}$ & $\begin{array}{c}\text { Heatflow } \\
\left(\mu \mathrm{cal} / \mathrm{cm}^{2} \mathrm{~s}\right)\end{array}$ & $\begin{array}{l}\text { Water } \\
\text { Temp. } \\
\left({ }^{\circ} \mathrm{C}\right)\end{array}$ & $\begin{array}{l}\text { Approx. } \\
\text { Sediment } \\
\text { Thickness } \\
\text { (m) }\end{array}$ & $\begin{array}{c}\text { Water } \\
\text { Depth } \\
\text { (m) }\end{array}$ & $\begin{array}{c}\text { Age } \\
\text { (m.y.) }\end{array}$ \\
\hline \multirow[t]{3}{*}{482} & $\mathrm{HF}-05$ & $22^{\circ} 46.8^{\prime} \mathrm{N}$ & $107^{\circ} 58.5^{\prime} \mathrm{W}$ & 0.647 & $1.82 \times 10^{-3 a}$ & $11.78 \pm 0.4$ & 1.670 & 147 & 2948 & 0.5 \\
\hline & HF-10 & $22^{\circ} 45.5^{\prime} \mathrm{N}$ & $108^{\circ} 21.0^{\prime} \mathrm{W}$ & 0.391 & $1.82 \times 10^{-3}$ & $7.12 \pm 0.3$ & $1.610^{b}$ & 62 & 2904 & 0.55 \\
\hline & HF-11 & $22^{\circ} 50.6^{\prime} \mathrm{N}$ & $107^{\circ} 35.7^{\prime} \mathrm{W}$ & 0.344 & $1.83 \times 10^{-3}$ & $6.30 \pm 0.4$ & 1.578 & 73 & 2845 & 1.6 \\
\hline 483 & HF-13 & $22^{\circ} 55.5^{\prime} \mathrm{N}$ & $108^{\circ} 42.9^{\prime} \mathrm{W}$ & 0.267 & $2.01 \times 10^{-3}$ & $5.37 \pm 0.4$ & 1.539 & 110 & 3005 & 2.4 \\
\hline 474 & HF-14 & $22^{\circ} 59.5^{\prime} \mathrm{N}$ & $108^{\circ} 59.2^{\prime} \mathrm{W}$ & 0.100 & $2.31 \times 10^{-3}$ & $2.31 \pm 0.5$ & 1.533 & 500 & 2954 & 3.5 \\
\hline
\end{tabular}

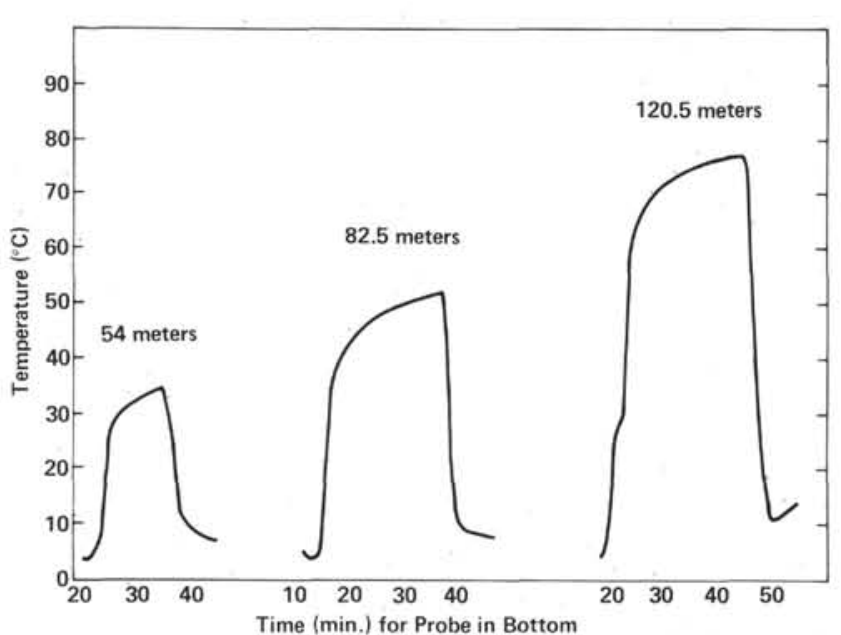

Figure 9. Temperature histories for three measurements at Site 482, Hole $482 \mathrm{C}$. (Steady-state temperatures were inferred by extrapolating the curves to large values of time. These temperatures were about $2-3^{\circ} \mathrm{C}$ above the highest temperatures recorded.)

would suggest that the final temperature could be considerably higher. At Site $\mathbf{4 8 2}$ the highest temperature recorded by the logging tool at the bottom of the hole was $40^{\circ} \mathrm{C}$ whereas we are reasonably certain that the formation temperature at this depth was at least $100^{\circ} \mathrm{C}$.

Site 474, 3.5 m.y.

This site was drilled on Leg 64 and the Tokyo TProbe was not successfully used. However, a temperature of $58^{\circ} \mathrm{C}$ was measured at 509 meters sub-bottom by the logging tool (Curray et al., in press). Again, this must be a lower bound.

\section{COMPARISON OF DOWNHOLE TEMPERATURES WITH TEMPERATURES INFERRED FROM SEAFLOOR HEAT FLOW DATA}

Three sites are available for comparison, Sites 482 , 483, and 474. Figure 11 shows the temperatures inferred at depth from the seafloor heat flow data using the Lister instrument compared with the observed downhole data. Note that these comparisons are only valid for the sediment columns.

For Site 482 the comparison is excellent, within a few ${ }^{\circ} \mathrm{C}$. For Site 483 , the correlation is less exact, either because of errors in the downhole data or because the temperature gradient in this section is not linear. Inferior data are more likely. For Site 474 , the single downhole datum (from the logging) is higher than the predicted temperature. This is significant since this datum is a lower bound. The reflection profile over this site shows a thin acoustically transparent layer that may be a recent turbidite deposit. This could depress the seafloor temperature gradient and account for the difference. This implies that the heat flow at Site $\mathbf{4 7 4}$ is greater than the value of $2.31 \mathrm{HFU}$ determined from the site survey measurements.

\section{THERMAL CONDUCTIVITIES OF SEDIMENTS AND BASALTS}

The in situ thermal conductivities determined with the Lister instrument are given in Table 1 and range from 1.82 to $2.01 \mathrm{mcal} / \mathrm{cm} \mathrm{s}^{\circ} \mathrm{C}$ for the topmost 1 meter of sediment. A value of 2.3 was found for the recent turbidites at Site 474 , which is substantially higher than the values at the other sites.

The thermal conductivities of sediment and basalt samples from Leg 65 were measured on the Glomar Challenger using shipboard equipment. This equipment uses a needle probe imbedded in an epoxy base and is a modification of the method described by Von Herzen and Maxwell (1959). This probe contains thermistors and a heater, and the conductivity is obtained from the rate at which the temperature measured on the thermistor rises. The conductivity $k=\mathrm{C} \ln \left(t_{2} / t_{1}\right) / T_{2}-T_{1}$, where $T_{2}$ and $T_{1}$ are temperatures at times $t_{2}$ and $t_{1}$ and $\mathrm{C}$ is a constant. The results are tabulated in Table 2 for sediments and basalts. The sediment values range from 1.8 to $2.1 \mathrm{mcal} / \mathrm{cm} \mathrm{s}^{\circ} \mathrm{C}$ and agree well with the seafloor in situ data. The basalt values range from 2.75 to 4.7 $\mathrm{mcal} / \mathrm{cm} \mathrm{s}^{\circ} \mathrm{C}$, with a mean of 3.37 for the samples from Hole 483B.

\section{INTERPRETATION OF HEAT FLOW RESULTS}

The preceding discussion of temperature and thermal conductivity data shows that the temperature gradients and in situ conductivities determined from the seafloor heat flow data are in accurate agreement with the data measured downhole from the Glomar Challenger. This confirms that the values of heat flow determined from the seafloor measurements represent a meaningful estimate of the heat flowing through the sediments. As a starting point for interpreting the heat flow data, these results will be compared with the Parker and Oldenburg (1973) thermal model for lithospheric cooling.

In this model the temperature at distance $x$ from the ridge crest and depth $z$ is given by 


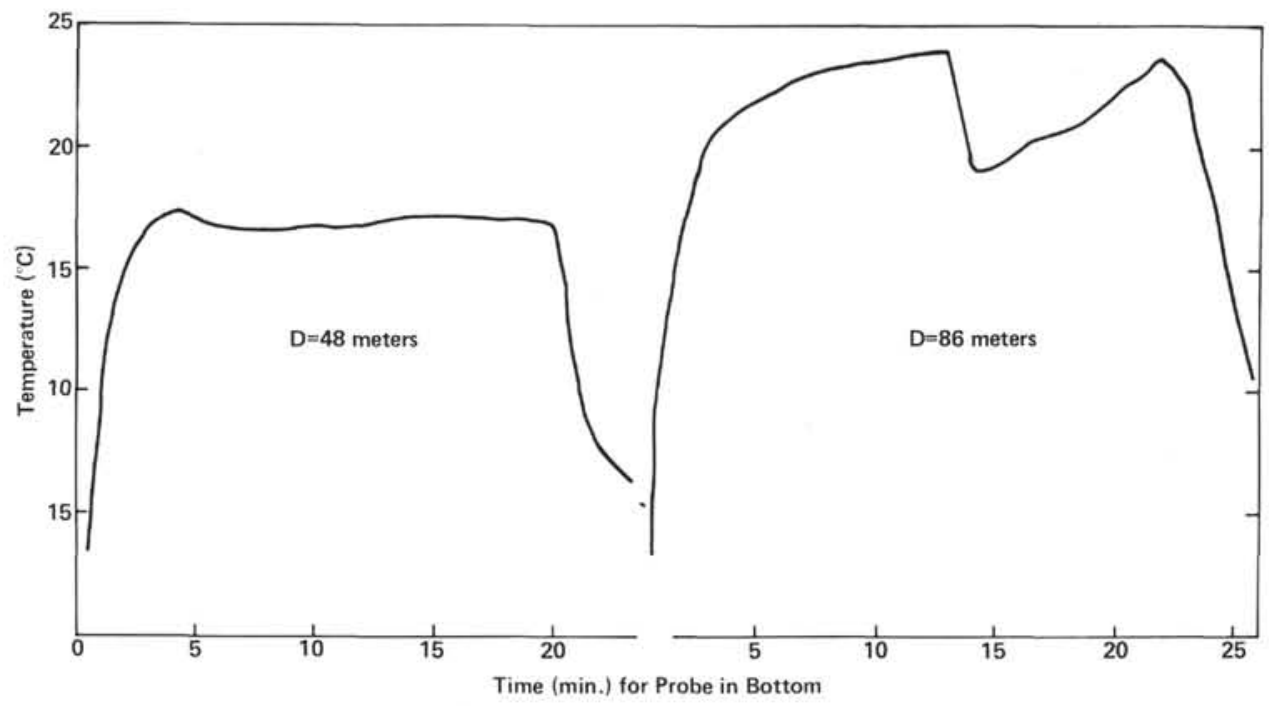

Figure 10. Temperature histories for Site 483, Hole 483C. (The measurement at 86 meters depth has an irregularity which was probably caused by the probe's having been withdrawn and reinserted into the bottom of the hole.)

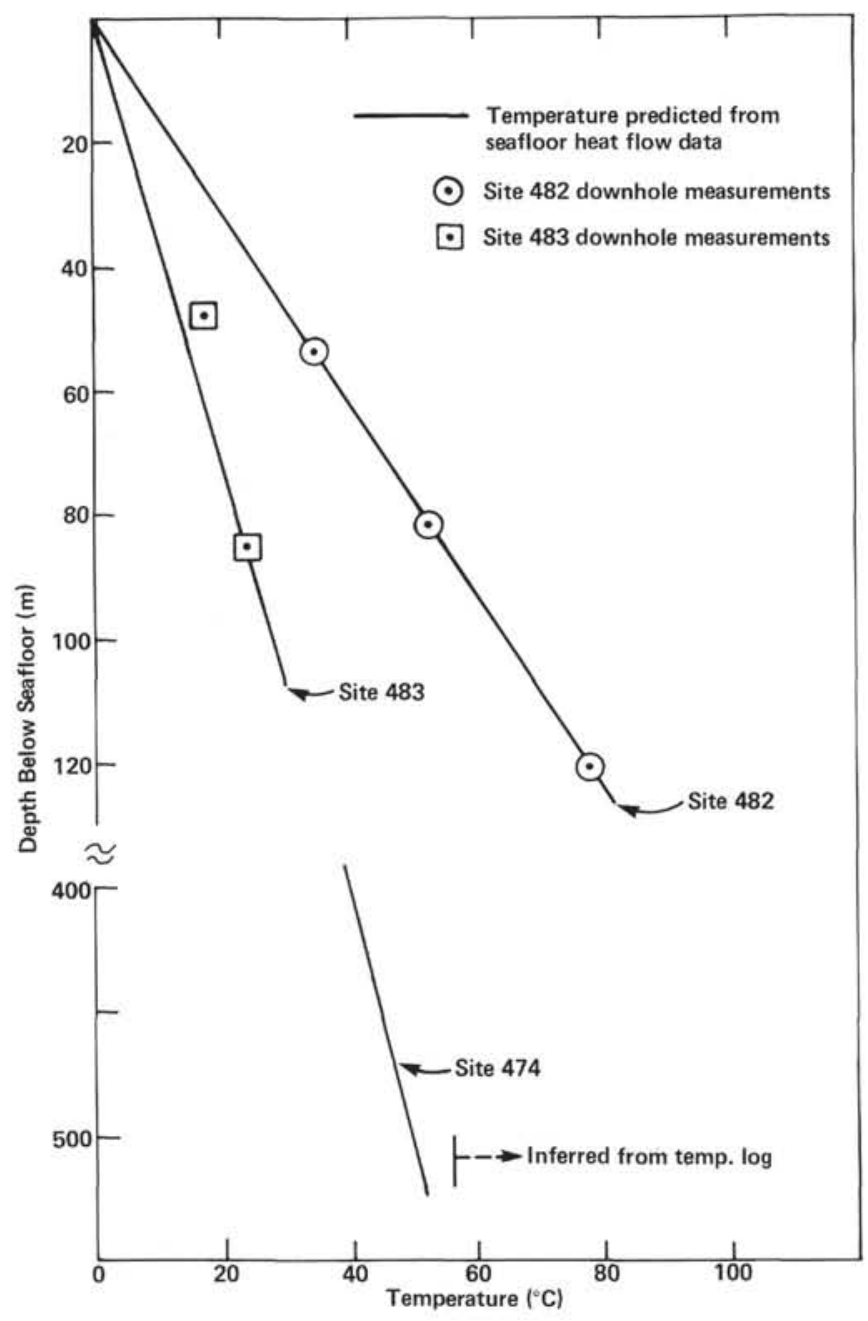

Table 2. Thermal conductivity of Leg 65 sediments and basalts.

Section $\begin{gathered}\text { Thermal Conductivity } \\ \left(\mathrm{mcal} \mathrm{cm}^{-1} \mathrm{~s}^{-1}{ }^{\circ} \mathrm{C}^{-1}\right)\end{gathered}$

\section{Basalts}

Hole 483B

$\begin{array}{ll}4-3 & 3.99 \\ 7-2 & 3.75 \\ 12-1 & 3.7 \\ 14-1 & 3.32 \\ 17-1 & 3.32 \\ 20-2 & 3.27 \\ 22-1 & 3.19 \\ 24-1 & 2.75 \\ 26-1 & 3.15 \\ 28-2 & 3.27 \\ 30-2 & 3.35\end{array}$

Hole $482 \mathrm{C}$

$\begin{array}{ll}13-2 & 4.32 \\ 13-2 & 4.72\end{array}$

Hole 482B

16-2

Sediments

Hole 483C

\begin{tabular}{ll}
$3-2$ & 1.90 \\
$3-2$ & 1.86 \\
$1-4$ & 2.11 \\
$1-4$ & 1.81 \\
\hline
\end{tabular}

Figure 11. Comparison of temperatures predicted from seabottom heat flow measurements with downhole temperatures obtained at Sites 482,483 , and 474 . 


$$
T(x, z)=T_{m} \operatorname{erf}\left[\frac{z}{2}\left(\frac{\varrho \nu \mathrm{C}_{p}}{k x}\right)^{1 / 2}\right]
$$

and the heat flow

$$
q(x)=T_{m}\left[\frac{k \varrho C_{p} \nu}{\pi x}\right]^{1 / 2}
$$

where $\varrho=$ density, $\nu=$ plate velocity, $C_{p}=$ specific heat, $k=$ thermal conductivity, $T_{m}=$ temperature at zero age (presumably the melting temperature), and erf is the error function.

In this model

$$
\frac{q(x)}{(t)^{-1 / 2}}=\left(\frac{k T_{m}^{2} \varrho C_{p}}{\pi}\right)^{1 / 2}
$$

and the heat flow is proportional to $(t)^{-1 / 2}$ where $t$ is the age of the lithosphere.

Figure 12 shows the heat flow data plotted versus $(t)^{-1 / 2}$ together with the theoretical curve from this model, assuming $T_{m}=1200^{\circ} \mathrm{C}, \varrho=3.14 \mathrm{~g} / \mathrm{cm}^{3}, C_{p}=$ $0.32 \mathrm{cal} / \mathrm{g}{ }^{\circ} \mathrm{C}$, and $k=4.2 \times 10^{-3} \mathrm{cal}^{\circ} \mathrm{C}^{-1} \mathrm{~cm}^{-1} \mathrm{~s}^{-1}$. With the exception of the data from Station HF-10, the data fit this model exceptionally well. This result may be contrasted with data from the Galapagos (Williams et al., 1974), where the cooling model fits the data very poorly close to the rise axis but fits better beyond an age of about $2 \mathrm{~m}$.y. The Galapagos results and similar results from other areas have been interpreted to imply that the conductive cooling model is not applicable close to the rise axis because of convective transport of heat caused by circulation of seawater through the oceanic crust.

The only station showing an obvious departure from conductive cooling is HF-10, and this may be due to convective cooling. Several questions still remain: Why do the other stations fit the conductive cooling model so well? Does this fit imply no convection below the sediment layer? Are the thermal parameters $k, T_{m}$, and $C_{p}$ reasonable for oceanic lithosphere? Each of these questions is considered separately.

Concerning the question of conductive cooling, it is noted that the geology of the area may be somewhat different from more typical oceanic seafloor generated far from an abundant supply of sediment. In Sites 482 and 485 , the basalt flows were predominantly massive, and at Site 485 these were interlayered with sediment (see Fig. 7.) This succession of relatively impermeable basalts interlain with sediments is hardly likely to sustain active water circulation. At Site 483, pillow basalts were more common between the massive flows. Here it is possible that the pillows are permeable but large scale convection within the sequence remains unlikely. It should also be noted that the drill sites were selected on the basis of having flat-lying basement covered with at least 100 meters of sediment. The ridges adjacent to drill Sites 482 and 485 are likely to be composed mostly of pillow basalts and therefore to be highly permeable. At these ridges with no sediment cover convective cooling is certainly likely to be important. Therefore, on the basis of the drill site selection criteria, these sites are heavily weighted toward areas that are likely to be impermeable at the surface.

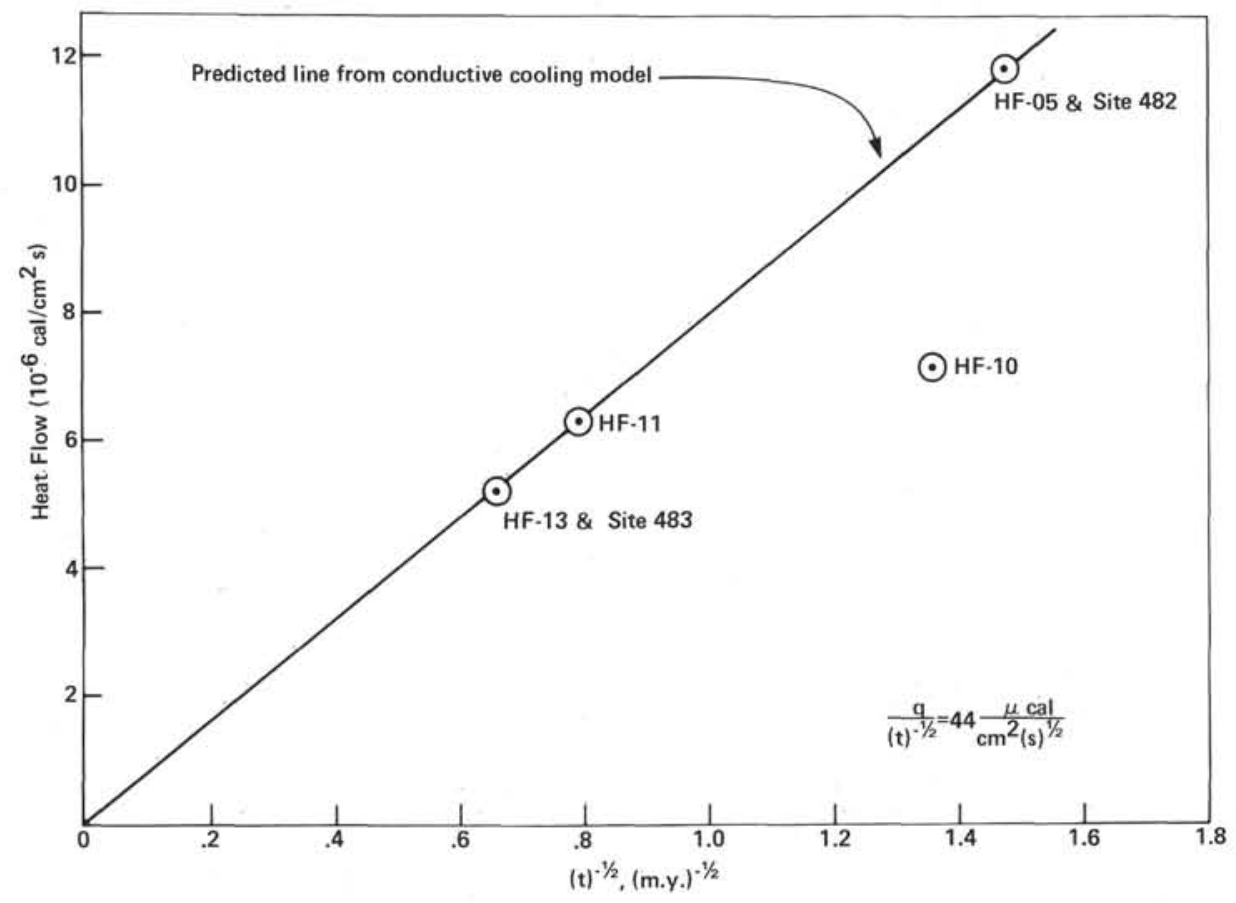

Figure 12. Observed heat flow values plotted against (age $)^{-1 / 2}$. (The line through the data represents theoretical values from the conductive cooling model of Parker and Oldenburg, 1973.) 
The excellent agreement between the observed heat flow data and the predictions of the conductive cooling model is either fortuitous or it suggests that the basic assumptions of the cooling model are valid in this area. The principal assumption is that heat is advected horizontally by the movement of material initially at temperature $T_{m}$ and that this heat is lost vertically by conduction. The model predicts a linear relationship between heat flow and (age $)^{-1 / 2}$ and, from the data, we ob-

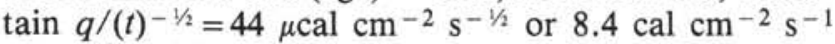
(m.y.) $)^{1 / 2}$, which is substantially lower than the value from old ocean floor measurements of $12 \mathrm{cal} \mathrm{cm}^{-2} \mathrm{~s}^{-1}$ (m.y.) ${ }^{1 / 2}$ reported by Lister (1980). This suggests differences in the thermal parameters between this area and "normal" lithosphere. From the model, $q /(t)^{-1 / 2}=T_{1}$ $\left(k_{\varrho} C_{p} / \pi\right)^{1 / 2}$. Since $\varrho$ and $C_{p}$ are unlikely to be greatly variable we must look to $T_{m} \sqrt{k}$ for differences. If we accept the measured conductivity of Leg 65 basalts $(\sim 3.4$ $\times 10^{-3} \mathrm{cal}^{\circ} \mathrm{C}^{-1} \mathrm{~cm}^{-1} \mathrm{~s}^{-1}$ ), and use $\varrho=2.8 \mathrm{~g} \mathrm{~cm}^{-3}$ for

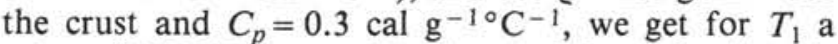

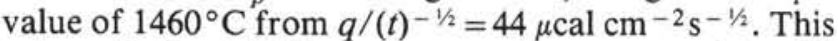
value of the initial temperature is unreasonable: (1) because it is much higher than the melting temperature of basalts, and (2) because it predicts temperatures at the base of the crust which are inconsistent with observed seismic velocities.

The most suspect assumption in the calculation is the applicability of laboratory measurements of $k$ to this environment. Both the porosities inferred from the velocities (Christensen and Lewis, this volume) and the inference of hot water flow from the Duennebier et al. (1980) experiment at Site 482 suggest that convective heat transport below the sediments may be taking place. In this situation the use of laboratory measurements of thermal conductivity to estimate temperatures will be grossly incorrect. A more reasonable approach would be to use an effective thermal conductivity $k_{\text {eff }}$ which implicitly includes nonconductive heat transport mechanisms in addition to the conductive component.

In an attempt to put limits on the value of $k_{\text {eff }}$, the seismic velocity of the top of the mantle at Site 482 was used. This value was $8.0 \mathrm{~km} / \mathrm{s}$. If we assume that a value of about $8.2 \mathrm{~km} / \mathrm{s}$ is representative of the velocity of old upper mantle at a temperature of about $200^{\circ} \mathrm{C}$ and allow for anisotropy, then the $8.0 \mathrm{~km} / \mathrm{s}$ value would imply a temperature increase of about $400^{\circ} \mathrm{C}$ using the value of $(\partial V / \partial T) P=-5.5 \times 10^{-4} \mathrm{~km} \mathrm{~s}^{-1}{ }^{\circ} \mathrm{C}^{-1}$ given by McClain (1979). This implies a temperature at the base of the crust at Site 482 of about $600^{\circ} \mathrm{C}$.

To obtain a value of $k_{\text {eff }}$ that was consistent with $600^{\circ} \mathrm{C}$ temperatures at the base of the crust at Site 482 , the thermal conductivity in the thermal model was varied until this condition was approached. Of course, to maintain the observed heat flow, the initial temperature $T_{1}$ in this model must also be varied. Implicit in these calculations is the assumption that horizontal heat transfer by convection is negligible and that the net heat flow through the impermeable surface layers is that available from advection by seafloor spreading.

Two temperature distributions which satisfy the observed heat flow are shown in Figure 13 superimposed on the crustal model of McClain and Lewis (1980). In both cases, a specific heat of $0.3 \mathrm{cal} \mathrm{g}^{-1{ }^{\circ}} \mathrm{C}^{-1}$, a crustal density of $2.8 \mathrm{~g} \mathrm{~cm}^{-3}$, and a mantle density of $3.3 \mathrm{~g}$ $\mathrm{cm}^{-3}$ were used. In the first case, $T_{1}=1380^{\circ} \mathrm{C}$ and $k_{\text {eff }}=4.0 \mathrm{cal}^{\circ} \mathrm{C}^{-1} \mathrm{~cm}^{-1} \mathrm{~s}^{-1}$; in the second case, $T_{1}=$ $1000^{\circ} \mathrm{C}$ and $k_{\text {eff }}=7.2 \mathrm{cal}^{\circ} \mathrm{C}^{-1} \mathrm{~cm}^{-1} \mathrm{~s}^{-1}$. The effect of surface sediments is not included in these calculations. The second case fits the seismic velocity data best, and one notes that the shape of the crust/mantle boundary is similar to the isotherms, suggesting that this boundary may be in part temperature-controlled.

Of course the topography predicted by this model does not fit the observations at all. I speculate that this is a consequence of the proximity of the Tamayo Fracture Zone. Here the viscous head loss argument of Sleep and Biehler (1970) may be applicable and could cause the axial valley. In this argument, heat from the athenosphere is lost by lateral conduction to colder lithosphere adjacent to the rise axis, and the viscosity is increased because of the lower temperatures in the ascending rock.

\section{CONCLUSIONS}

It has been shown that the Leg 65 downhole temperature data and sediment thermal conductivities agree well with seafloor heat flow measurements made during the site survey conducted prior to drilling. The areas drilled were generally characterized by massive basalts interlain with sediments and overlain by sediments, conditions which should restrict convective cooling. A comparison of observed heat flow data versus age is in excellent agreement with the conductive cooling model of Parker and Oldenburg (1973). However, it is suggested that this agreement only implies that the heat flux through the impermeable surface layers agrees with the conductive model. Below the surface layers, some degree of convective heat transport is required in order to reduce the temperature at the base of the crust to values consistent with the observed seismic velocities. A temperature distribution was calculated from a model having a high effective thermal conductivity which fits the observed heat flow and is consistent with observed seismic velocities. This model requires an effective thermal conductivity in the crust which is about twice the conductivity measured on Leg 65 basalts. This is interpreted as the influence of convective heat transport on the effective conductivity.

\section{ACKNOWLEDGMENTS}

I would like to thank Clive Lister for allowing the use of his heat flow instrument during the Thomas G. Thompson site survey, Bill Snydsman for reducing the heat flow data, the technical staff of the Deep Sea Drilling Project for their assistance during and after the cruise, and the crew of the Glomar Challenger for the downhole temperature measurements. (U.W. Contribution, No. 1140).

\section{REFERENCES}

Anderson, R. C., Langseth, M. G., and Sclater, J. G., 1977. The mechanisms of heat transfer through the floor of the Indian Ocean. J. Geophys. Res., 82:3391-3409.

Curray, J. R., Moore, D. G., et al., in press. Site 474. Init. Repts. $D S D P, 64$ : Washington (U.S. Govt. Printing Office).

Duennebier, F., and Blackinton, G., 1980. A man-made hot spring on the ocean floor. Nature, 284(5754):338-340. 
Hyndman, R. D., Von Herzen, R. P., Erickson, A. J., and Jolivet, J., 1976. Heat flow measurements in deep crustal holes on the MidAtlantic Ridge. J. Geophys. Res., 81:4053-4060.

Lister, C.R.B., 1970. Measurement of in situ sediment conductivity by means of a Bullard-type probe. Geophys. J. R. Astron. Soc., 19:521-532.

1972. On the thermal balance of a mid-ocean ridge. Geophys. J. R. Astron. Soc., 26:515-535.

1980. Estimators for heat flow and deep rock properties based on boundary layer theory. In Toksöz, M. N., Uyeda, S., and Francheteau, J. (Eds.), Oceanic Ridges and Arcs: Amsterdam (Elsevier Scientific Publishing Co.), pp. 127-141.
McClain, J. S., 1979. The implications of Pn amplitudes for velocity gradients in the uppermost oceanic mantle [Ph.D. dissert.]. University of Washington.

McClain, J. S., and Lewis, B.T. R., 1980. A seismic experiment at the axis of the East Pacific Rise. Mar. Geol., 35:147-169.

Parker, R. L., and Oldenburg, D. W., 1973. Thermal model of ocean ridges. Nature, 242:137-139.

Sleep, N. H., and Biehler, S., 1970. Topography and tectonics at the intersection of fracture zones with central rifts. J. Geophys. Res., $75: 2748-2752$.

Von Herzen, R., and Maxwell, A. E., 1959. The measurement of thermal conductivity of deep-sea sediments by a needle-probe method. J. Geophys. Res., 64:1557-1563.
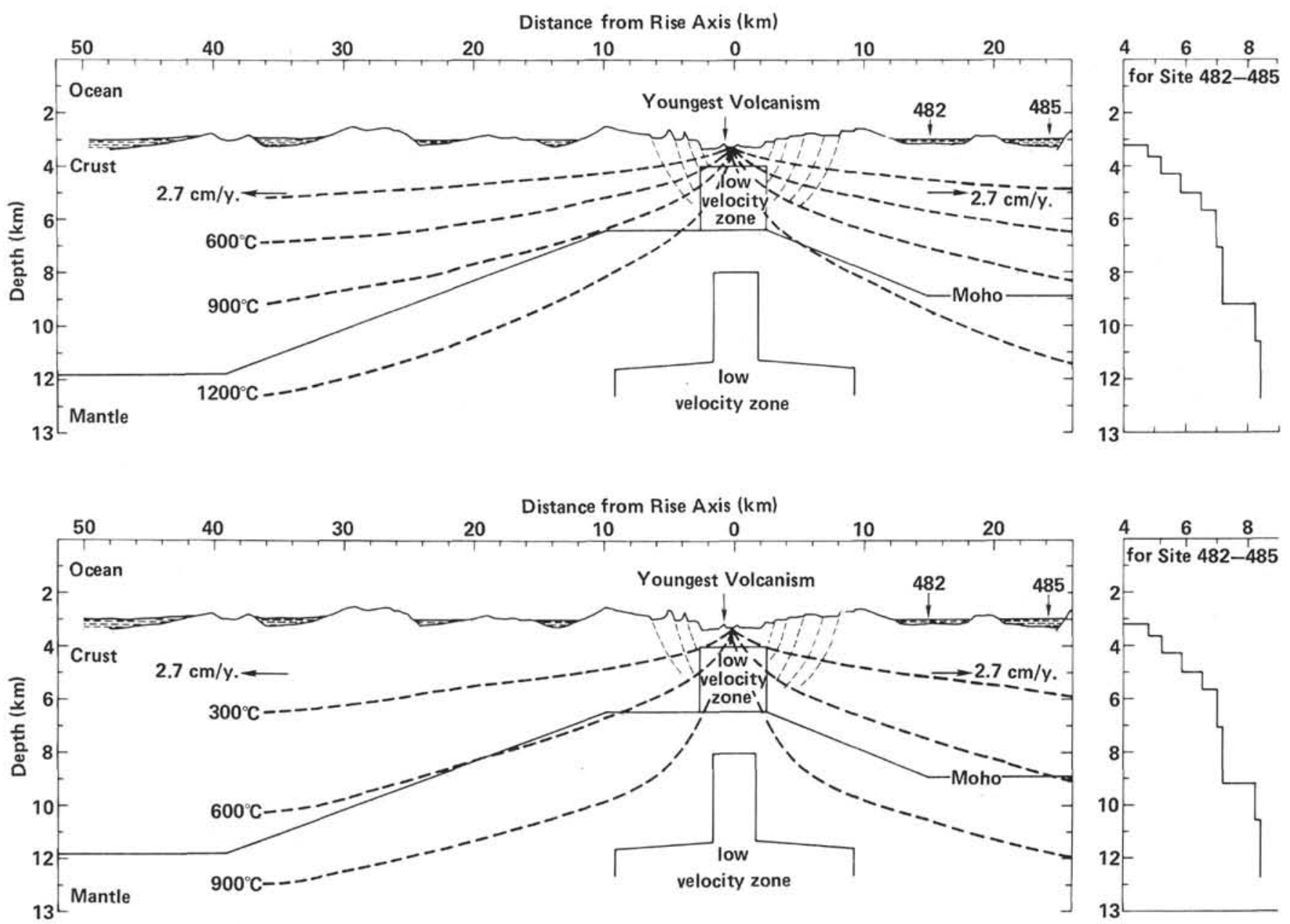

Figure 13. Two temperature distributions which satisfy the observed heat flow in the mouth of the Gulf of California, superimposed on the crustal model of McClain and Lewis (1980). (In the upper case, $T_{1}=1380^{\circ} \mathrm{C}$ and $k_{e f f}=4.0 \mathrm{cal}{ }^{\circ} \mathrm{C}^{-1} \mathrm{~s}^{-1} \mathrm{~cm}^{-1}$; in the lower case, $T_{1}=1000^{\circ} \mathrm{C}$ and $k_{\text {eff }}=7.2 \mathrm{cal}{ }^{\circ} \mathrm{C}^{-1} \mathrm{~s}^{-1} \mathrm{~cm}^{-1}$. The lower temperatures at the base of the crust in the second case are consistent with observed seismic velocities.) 